\title{
Morenia petersi Anderson 1879 - Indian Eyed Turtle
}

\author{
Indraneil Das ${ }^{1}$ and Saibal Sengupta ${ }^{2}$ \\ ${ }^{1}$ Institute of Biodiversity and Environmental Conservation, \\ Universiti Malaysia Sarawak, 94300 Kota Samarahan, Sarawak, Malaysia \\ [idas@ibec.unimas.my]; \\ ${ }^{2}$ Department of Zoology, Arya Vidyapeeth College, Guwahati 781 016, Assam, India \\ [senguptasaibal@yahoo.co.in]
}

\begin{abstract}
Summary. - The Indian eyed turtle, Morenia petersi (Family Geoemydidae), is a small freshwater turtle (carapace length to $222 \mathrm{~mm}$ ) with a fairly restricted distribution in northern, eastern, and northeastern India, southern Nepal, and Bangladesh. The species may be locally common in some areas, especially in Bangladesh. It is exclusively herbivorous in the wild, with jaw surfaces highly specialized for folivory. It nests in winter, laying a single clutch of 6-10 elongate, slightly tapered eggs, measuring about $50 \times 20 \mathrm{~mm}$. The species appears to be threatened by heavy exploitation in Bangladesh.

Distribution. - Bangladesh, India, Nepal. Distributed across northern India, southern Nepal, and Bangladesh.
\end{abstract}

SynONYMy. - Batagur (Morenia) petersi Anderson 1879, Morenia petersi.

SubSPECIES. - None recognized.

STATUS. - IUCN 2010 Red List: Vulnerable (A1cd+2d) (assessed 2000); CITES: Not Listed.

Taxonomy. - Morenia petersi was described from Bengal, British India, by Anderson (1879), in honor of Wilhelm C.H. Peters (1815-1883), of the Zoologisches Museum Humboldt-Universität, Berlin, who advised Anderson that he considered the true Burmese species to be Morenia ocellata, thus clarifying that the Bengal species was in need of a new name. Anderson (1879) discussed the confusion that derived from Duméril and Bibron's (1835) error in considering that M. ocellata originated from Bengal. The syntypes of $M$. petersi were collected in Huzurapur (Jessore District), Furreedpore, and Dacca (now Dakha) in British India's Bengal Province (these localities now in Bangladesh).
No subspecies have been described. The only other member of its genus is the Burmese eyed turtle (M.ocellata), which is endemic to Myanmar, with a possible extension into southwestern Yunnan, China (Kuchling 1995).

Description. - The carapace is somewhat domed, with a low or absent vertebral keel in adults, and unserrated marginals. In juveniles, the shell is higher and the vertebral keel is strongly nodose. The nuchal scute is relatively broad; about $50 \%$ of the width of the first marginal. The first vertebral is longer than wide, with a convex anterior margin and a concave posterior one; vertebrals 2 to 4 are broader than long, becoming progressively shorter from front to back.

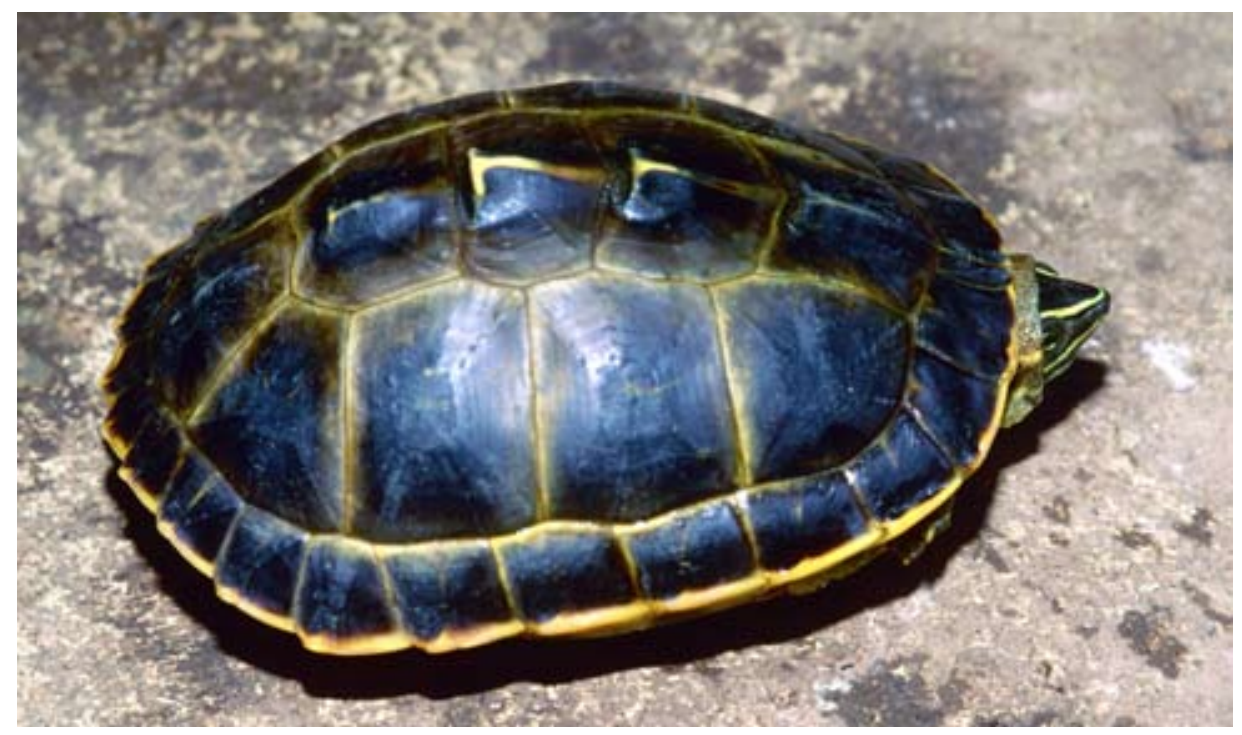

Figure 1. Morenia petersi, adult female from Sylhet, Bangladesh. Photo by Indraneil Das. 


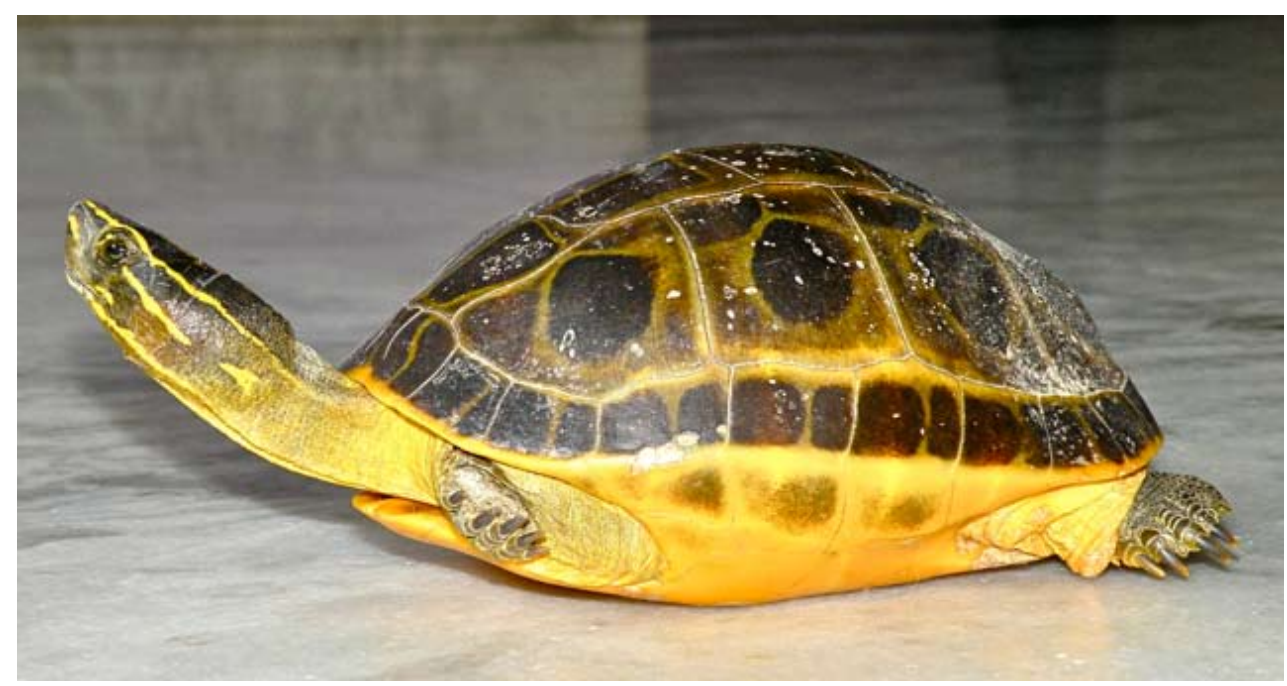

Figure 2. Morenia petersi, adult female from Ganga River, Uttar Pradesh, India. Photo by Shailendra Singh.

The plastron is relatively wide, notched posteriorly, and with the flanks of the hind lobe smoothly curved, contrasting with M.ocellata where there is a constriction at the femoroanal seam. The gulars are relatively short, barely encroaching upon the entoplastron if they do at all. Anderson (1879) gave extensive details of the differences in the scute seam ratios in the two species of Morenia.
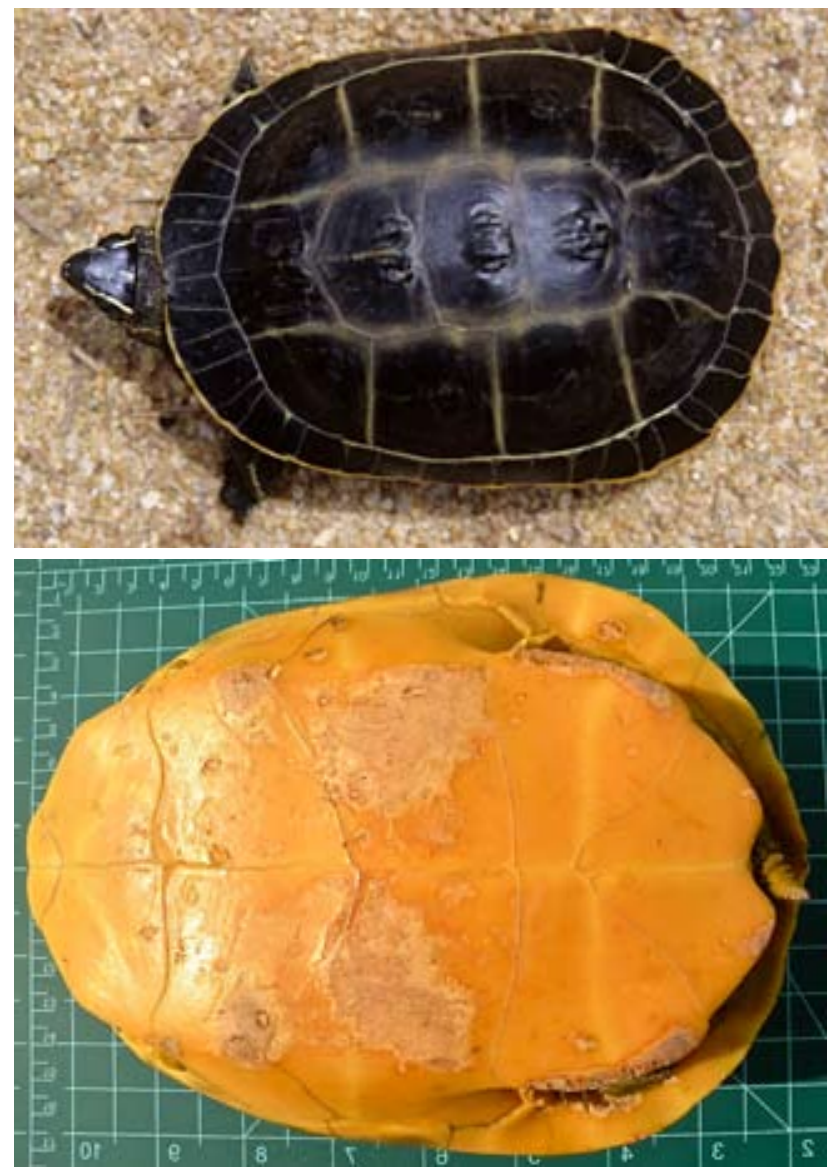

Figure 3. Morenia petersi, adult females from Bihar, India (top, photo by Indraneil Das) and Ganga River, Uttar Pradesh, India (bottom, photo by Shailendra Singh).
The head is small, with a strikingly pointed snout, covered on top and on the sides with large scales, with small scales on the posterior of the head.

The carapace is green, olive, or gray-black. The vertebrals and costals are bordered with green or yellow, the first four vertebrals are striped with green and each bears a U-shaped mark. Typically, pale green circles and looped lines are present on the costals. The carapacial markings may form true ocelli, but these tend to be larger and more rambling than in M. ocellata, and are often incomplete or even absent. The plastron is yellow or orange, usually with black blotches on the axillary scutes and some of the adjacent marginals. The head is olive with three yellow stripes on each side, the first on top of the eyes, the second over the jaws, and the third behind the eyes. The limbs are yellow-margined and the digits are webbed.

The neural bones are typically hexagonal with the short sides anteriorly, but wide variation occurs. For example, an octagonal element may be present, most often at position 3 , and even within the series of hexagonal neurals, erratic changes in size and shape may occur from front to back.

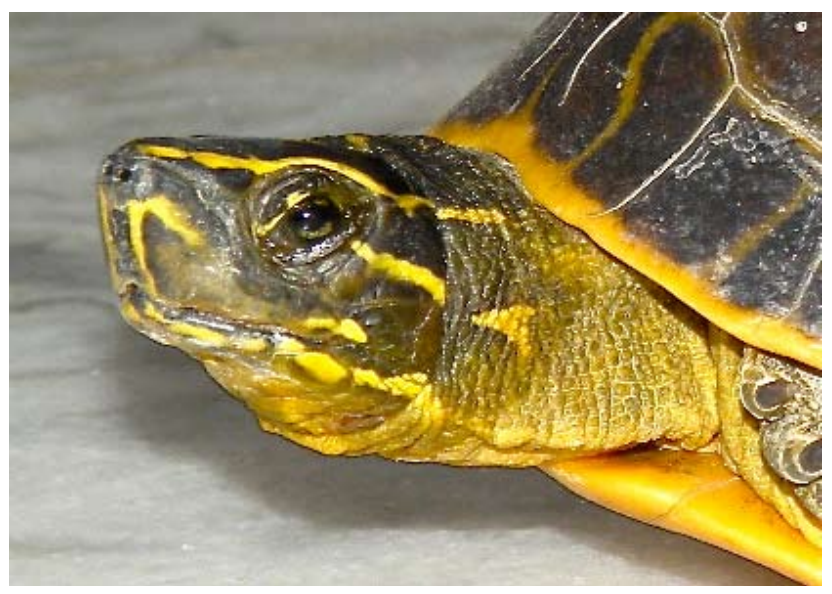

Figure 4. Morenia petersi, adult female from Ganga River, Uttar Pradesh, India. Photo by Shailendra Singh. 


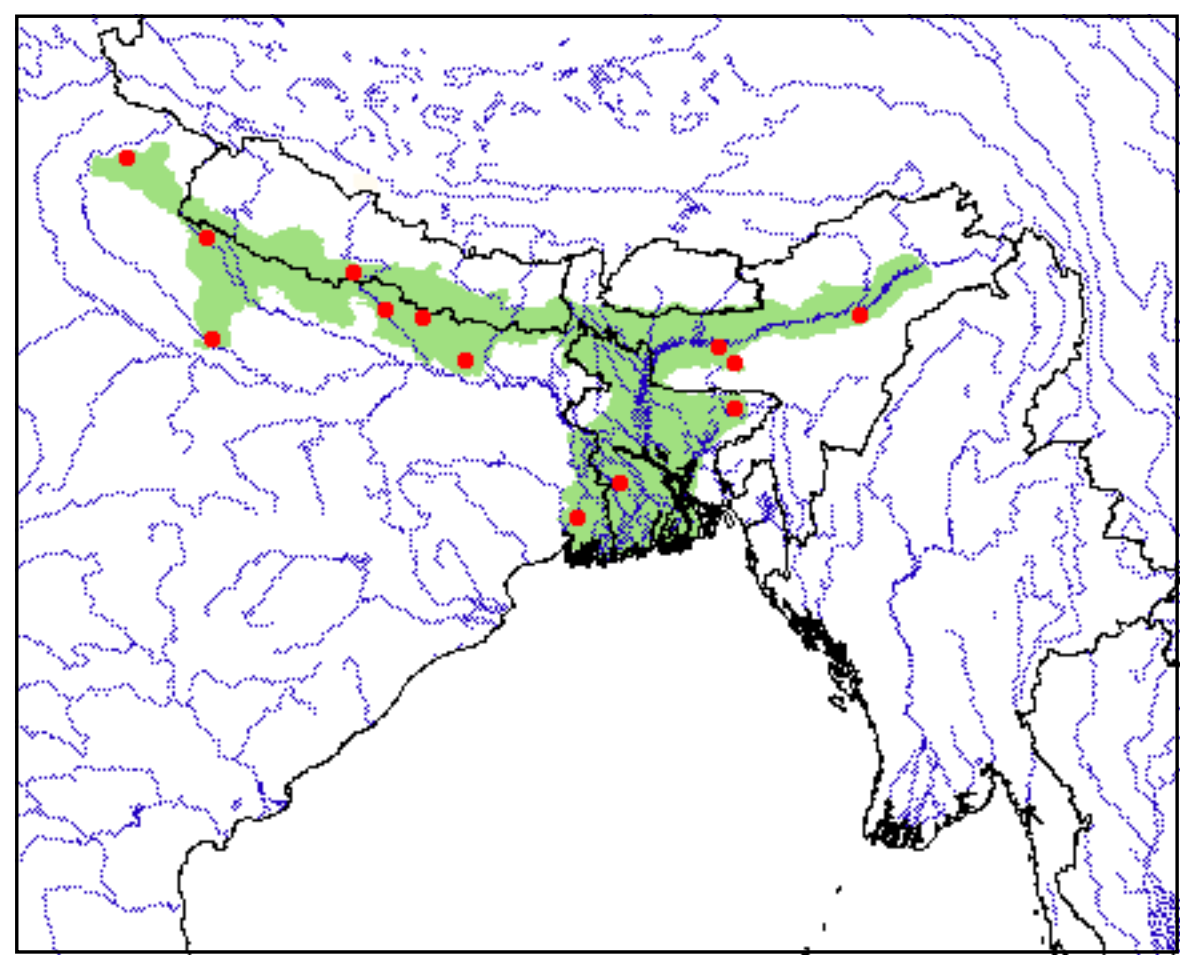

Figure 5. Distribution of Morenia petersi in India, Nepal, and Bangladesh. Red points = museum and literature occurrence records based on Iverson (1992) plus more recent and authors' data; green shading = projected distribution based on GIS-defined hydrologic unit compartments (HUCs) constructed around verified localities and then adding HUCs that connect known point localities in the same watershed or physiographic region, and similar habitats and elevations as verified HUCs (Buhlmann et al. 2009), and adjusted based on authors' data.

In the majority of specimens examined ( 8 out of 14$)$, there was contact between the eighth pair of pleural bones at the midline, a phenomenon not seen in Morenia ocellata. The frequently well-marked alternation in width of the distal ends of the pleural bones, of which numbers 1,3 , and 5 are widened and 2, 4, and 6 narrowed, is reminiscent of the condition in many testudinids.

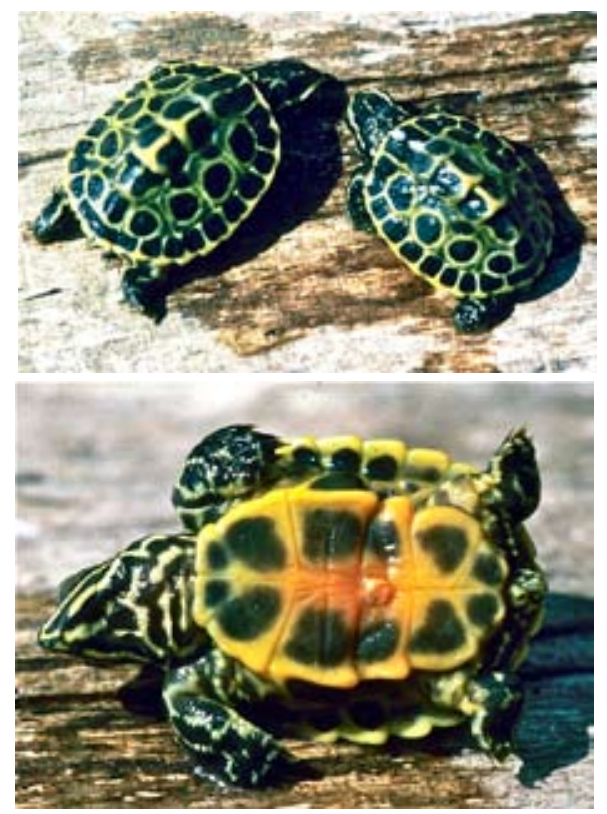

Figure 6. Morenia petersi, hatchlings of unknown provenance. Photos by Hans-Dieter Philippen.
The jugal arch is complete, and the upper jaw anteriorly bicuspid. The jaws are narrower than in M. ocellata, but the biting surfaces are just as elaborate and equally specialized for folivory.

Male carapace length (CL) is considerably shorter than in females. A group of "large males" (i.e., those with CL more than $160 \mathrm{~mm}$ ) measured by Rashid and Swingland (1997) had a mean CL of $178.8 \mathrm{~mm}$ (range 163-194); whereas "large females" (i.e., those longer than $180 \mathrm{~mm}$ ) had a mean CL of $195.6 \mathrm{~mm}$ (range 180-222). The largest female weighed $1150 \mathrm{~g}$. In addition to being smaller, males have longer tails, with the vent usually lying beyond the posterior rim of the carapace. The anal notch is relatively deeper in males, and the posterior end of the shell is more rounded in females. The posterior part of the plastron in males has an elongate concavity.

The karyotype is unknown and no genetic or phylogeographic studies have yet been done as far as known.

Distribution. - The Indian eyed turtle is restricted to the drainages of the Ganga and the western Brahmaputra rivers, apparently well above tidal limits. Its distribution includes Bangladesh and the Indian states, extending from Uttarkhand (Haridwar, near the source of the River Ganga; Bahuguna 2010), through Uttar Pradesh, Bihar, West Bengal, Assam, and Manipur. The western-most record for the species is Dudhwa National Park, Uttar Pradesh, reported by Javed and Hanfee (1995). It has recently also been found at Kanpur, River Ganga (S. Singh, unpubl. data). In Bangladesh, Rashid and Swingland (1997) reported that it is 
uncommon but somewhat widely distributed in the districts of Faridpur, Comilla, Noakhale, Brahmanbaria, Barisal, Bakerhat, Manikganj, Pabna, Jessore, Dhaka, Netrokona, and Mymensingh. The record from Nepal is from Gaindatal, Bishanapur, Rupandehi District (Shah 1999; Schleich and Kästle 2002).

Habitat and Ecology. - The species occurs in a variety of aquatic situations, including rivers as well as standing waterbodies, from the Terai and Bhabar tracts of the Himalayan foothills, to the plains of eastern India and Bangladesh. Moll and Vijaya (1986) found this turtle in weed-choked nullahs with little current, and also in oxbow lakes, although Khan (1987) noted that the species prefers stagnant water bodies. The same author observed it to bask in rows on sandbars and on sandbanks along eroded river banks (Khan 1982). Rashid and Swingland (1997) reported the typical habitat in Bangladesh to be shallow, standing water, including large "tanks," pools, puddles, ponds, "haors" (= extensive, lake-like standing bodies of water), and slow-flowing canals and streams. Oxbow lakes were typical habitat. The turtles spend much time at the water's edge and usually bask by resting their limbs and head on floating objects. They are shy and alert, diving and swimming away at the slightest disturbance.

Rashid and Swingland (1997) reported that the species was herbivorous in Bangladesh, feeding upon both floating and submerged vegetation, including water hyacinth and Hydrilla. Their examination of stomach contents of seven wild turtles revealed only vegetable material. The highlydeveloped jaw surfaces parallel those of such unrelated turtles as Dermatemys mawii, and are specialized for folivory, a diet of leaves (see Moll and Moll 2004).

Schleich and Kästle (2002) reported that females mature at a CL of $180 \mathrm{~mm}$ and mass of $650 \mathrm{~g}$, nesting in loamy soil with sparse vegetation in undisturbed areas with open sunlight. A female collected from Bangladesh laid two eggs in captivity, measuring $35 \times 22$ and $34.6 \times 22 \mathrm{~mm}$, between the end of April and the beginning of May, which coincides with the beginning of the dry season in the natural range of the species (P.C.H. Pritchard, unpubl. data). However, this observation may be abnormal, in that Rashid and Swingland (1997) reported nesting in winter (late December to late January), with no evidence of multiple clutching. Oviposition typically occurs at night, nests containing 6-10 elongate, slightly tapered white eggs. Average dimensions were 49.5 x $20.2 \mathrm{~mm}$, and average mass was $10.3 \mathrm{~g}$. Emergence was reported to be encountered in the months of April-May (Rashid and Swingland 1997).

Population Status. - No information available. This species has been reported as still abundant in parts of Bangladesh where larger freshwater turtle species have become rare through overexploitation (Sarker and Hossain 1997), while others have mentioned that it is uncommon (Rashid and Swingland 1997; Rashid and Khan 2000).

Threats to Survival. - As with other aquatic turtles, the damming of rivers, conversion of waterbodies into agricultural fields, and pollution by sewage, fertilizer, and pesticide runoff are factors thought to impact the species negatively. Some are caught for local consumption by the Hindus in Bangladesh (Khan 1982; Das 1991). Rashid and Swingland (1997) and Rashid and Khan (2000) reported that the catch for food in Bangladesh was considerable, and was effected mostly with spears or nets. The species has also been reported in the international food trade in southern China, including being found in markets in Hainan and Hong Kong (DeBruin and Artner 1999; Cheung and Dudgeon 2006).

Conservation Measures Taken. - Although not protected by specific legislation, the listing of M. ocellata in Schedule III of the Bangladesh Wildlife Preservation Act, presumably as an erroneous reference to $M$. petersi in that only the latter species occurs in Bangladesh, may provide some protection. The confusion between the species may be a lingering result of the 19th century misinformation about the distribution of each of the two species. The species is listed in the Red Data Book of Nepal (Shah and Tiwari 2004). It is currently listed as Vulnerable on the IUCN Red List (www.iucnredlist.org).

The species occurs in some protected areas, including Dudhwa National Park in Uttar Pradesh, India, close to the Nepal border (Javed and Hanfee 1995). There are three records from protected areas in Assam, India: Deepor Beel Ramsar Site (Baruah and Sharma 2010), Kaziranga National Park (Choudhury 2004), and Pobitora Wildlife Sanctuary (Sengupta et al. 1998). The Haridwar locality in Uttarkhand (Bahuguna 2010) suggests its occurrence in nearby Rajaji National Park.

Conservation Measures Proposed. - This species appears to have a more restricted distribution than most of the turtle species with which it shares its range, but the details of its distribution and population status remain unclear and need to be investigated in the range states before specific conservation actions can be devised. Continued monitoring of exploitation levels for the international food trade is necessary as well.

Captive Husbandry. - Morenia petersi has never been widely available in the pet trade and is rarely, if ever, seen in zoos. Two pairs are maintained at a private collection in Vienna at the time of writing, and W.P. McCord of New York has kept specimens in captivity in recent years. Captive maintenance for protracted periods seems difficult, most specimens showing erosion of the thin shell scutes by the time they reach collections, and this erosion then often becomes infected and spreads through the bone. Fish and prawn are preferred to plant food in captivity (Khan 1987).

Current Research. - No information.

Acknowledgments. - Supported by the Centre for Herpetology, Madras Crocodile Bank Trust, Universiti Malaysia Sarawak, and Arya Vidyapeeth College. We thank Genevieve V.A. Gee, John B. Iverson, Shailendra Singh, and Peter C.H. Pritchard for unpublished data and comments on the manuscript, and Shailendra Singh and Hans-Dieter Philippen for photos. 


\section{LITERATURE CITED}

ANDERSON,J.1879 ["1878"].Anatomical and Zoological Researches: Comprising an Account of the Zoological Results of the Two Expeditions to Western Yunnan in 1868 and 1875; and a Monograph of the Two Cetacean Genera, Platanista and Orcella. Bernard Quaritch, London. Vol. I, 984 pp., Vol. II, 29 pp).

BAHUGUnA,A. 2010.Geographic distribution.Morenia petersi (Indian eyed turtle). Herpetological Review 41(2):242.

Baruah, C. AND Sharma, D.K. 2010. Indian eyed turtle Morenia petersi (Anderson, 1879) in the Deepor Beel, Ramsar site. ReptileRap 9:6-7.

Buhlmann, K.A., Akre, T.S., Iverson, J.B., Karapatakis, D., MitTERMEIER, R.A., GEORGES, A., RHODIN, A.G.J., vAN DiJK, P.P., AND GibBons, J.W. 2009. A global analysis of tortoise and freshwater turtle distributions with identification of priority conservation areas. Chelonian Conservation and Biology 8(2):116-149.

Cheung, S.M. And Dudgeon, D. 2006. Quantifying the Asian turtle crisis: market surveys in southern China, 2000-2003. Aquatic Conservation: Marine and Freshwater Ecosystems 16:751-770.

CHOudhury, A. 2004. Kaziranga: Wildlife in Assam. Kolkata: Rupa \& Co., 104 pp.

DAS, I. 1991. Colour Guide to the Turtles and Tortoises of the Indian Subcontinent. R \& A Publishing Limited, Portishead, 133 pp.

De Bruin, R.W.F. AND ARTNER, H.G. 1999. On the turtles of Hainan Island, southern China. Chelonian Conservation and Biology 3:479-486.

DumÉRIL,A.M.C.AND BIBRON,G. 1835.Erpétologie Générale ou Histoire Naturelle des Reptiles. Tome Second. Paris: Roret, 680 pp.

Iverson, J.B. 1992. A Revised Checklist with Distribution Maps of the Turtles of the World. Privately published, Richmond, Indiana, $363 \mathrm{pp}$.

JAVED,S. ANDHANFEE,F. 1995. Freshwater turtles of Dudhwa National Park and their conservation. Hamadryad 20:21-26.

KHAN,M.A.R.1982.Chelonians of Bangladesh and their conservation. Journal of the Bombay Natural History Society 79:110-116.

KHAN, M.A.R. 1987. Bangladesher Bonnyoprani. Vol. I. Urochor o Shorishrip. Bangla Academy, Dhaka. 169 pp.

KuCHLING, G. 1995. Turtles at a market in western Yunnan: possible range extensions for some southern Asiatic chelonians inChina and Myanmar. Chelonian Conservation and Biology 1:223-226.

Moll, D. And Moll, E.O. 2004. The Ecology, Exploitation, and Conservation of River Turtles. New York: Oxford University Press, 393 pp.
Moll, E.O. and ViJaYA, J. 1986. Distributional records for some Indian turtles. Journal of the Bombay Natural History Society 83:57-62.

RASHID, S.M.A. AND KHAN, S.M.M.H. 2000. Trade and conservation status of turtles and tortoises in Bangladesh.In: vanDijk,P.P., Stuart, B.L., and Rhodin,A.G.J.(Eds.).Asian Turtle Trade:Proceedings of a Workshop on Conservation and Trade of Freshwater Turtles and Tortoises in Asia. Chelonian Research Monographs 2:77-85.

RASHID, S.M.A. AND SwINGLAND, I.R. 1997. On the ecology of some freshwater turtles in Bangladesh. In: Van Abbema, J. (Ed.). Proceedings: Conservation, Restoration, and Management of Tortoises and Turtles - An International Conference. New York Turtle and Tortoise Society, New York, pp. 225-242.

SARKER, S.U.M. AND Hossain, L.M. 1997. Population and habitat status of freshwater turtles and tortoises of Bangladesh and their conservation aspects. In: Van Abbema, J. (Ed.). Proceedings: Conservation, Restoration, and Management of Tortoises and Turtles - An International Conference. New York: New York Turtle and Tortoise Society. pp. 290-294.

Schleich, H.H. AND KästLE, W. 2002. Order Chelonia/Testudines (turtles: terrapins and tortoises). In: Schleich, H.H. and Kästle, W. (Eds). Amphibians and Reptiles of Nepal. Biology, Systematics, Field Guide. Koeltz Scientific Books, Koenigstein, pp. 501-573.

Sengupta, S., Baruah, M.R., Baruah, M. and Choudhury, N.K. 1998. Report on turtles of Pobitora Wildlife Sanctuary. Journal NATCON 10(2):209-210.

SHAH,K.B. 1999. New records and distribution of some herpetofauna of Nepal. Journal of the Natural History Museum, Kathmandu 18:99-111.

SHAH, K.B. AND TIWARI, S. 2004. Herpetofauna of Nepal.AConservation Companion. IUCN Nepal, Kathmandu, 237 pp.

\section{Citation Format for this Account:}

Das, I. And Sengupta, S. 2010. Morenia petersi Anderson 1879 Indian eyed turtle.In: Rhodin,A.G.J., Pritchard,P.C.H., van Dijk, P.P., Saumure, R.A., Buhlmann, K.A., Iverson, J.B., and Mittermeier, R.A. (Eds.). Conservation Biology of Freshwater Turtles and Tortoises: A Compilation Project of the IUCN/SSC Tortoise and Freshwater Turtle Specialist Group. Chelonian Research Monographs No. 5, pp. 045.1-045.5, doi:10.3854/crm.5.045. petersi.v1.2010, http://www.iucn-tftsg.org/cbftt/. 